\title{
Ernesto Quesada, a Positivist Traveler. Between Cosmopolitism and Scientific Patriarchy
}

\author{
Axel Gasquet \\ Université Blaise Pascal (CERHAC), Clermont-Ferrand, France \\ e-mail: axel.gasquet@univ-bpclermont.fr
}

Received: 11 July 2012; Accepted: 13 September 2012; Published online: 8 January 2013

\begin{abstract}
Ernesto Quesada (1858-1934) was a renowned and prolific intellectual of the 1890 generation in Argentina. With his father, Vicente Gaspar Quesada, he co-directed Nueva Revista de Buenos Aires between 1863 and 1871. Sociologist, Professor, Germanist and publicist, Quesada was a well-known representative of positivism. A true cosmopolitan, Quesada stood out as a traveler among his peers who were used to extensive journeys, especially in the west. He embarked on unconventional paths for the Argentineans of his time; in 1884 he traveled to Russia and around the world in 1913. These experiences are registered in A Winter in Russia (1888) and Around the World (1914), texts that have not been subject to critique until now. There are thirty years of intense intellectual work from one book to the other. We will study them in the light of his work and time, when a new vision about the Middle and Far East -independent from Europe- was born in Argentina. This contributed to create the model for a modern liberal state for the Argentinean nation. This timespan goes from the federalization of Buenos Aires (with the founding of $\mathrm{La}$ Plata as provincial capital in 1882) to the opulence of the centenary (1910).
\end{abstract}

KEYWORDS: Ernesto Quesada; positivism; cosmopolitism; travel literature; Russia; Eastern Countries

Citation / Cómo citar este artículo: Gasquet, Axel (2012) "Ernesto Quesada, a Positivist Traveler. Between Cosmopolitism and Scientific Patriarchy". Culture \& History Digital Journal 1(2): m107. doi: http://dx.doi.org/10.3989/ chdj.2012.m107

RESUMEN: Ernesto Quesada, un viajero positivista. Entre el cosmopolitismo y el patriarcado científico.- Ernesto Quesada (1858-1934) fue una de las personalidades intelectuales más conocidas y prolíficas de la generación de 1890 en la Argentina. Hijo de Vicente Gaspar Quesada, co-dirigió con su padre la Nueva Revista de Buenos Aires entre 1863 y 1871. Sociólogo, catedrático, germanista y publicista, Quesada fue un gran representante del pensamiento positivista. De cultura cosmopolita, Quesada se distingue asimismo por ser un notable viajero entre una generación que transitó extensamente el mundo, especialmente el occidental. Quesada fatigó además derroteros poco convencionales para los rioplatenses de su época, en especial durante su periplo por Rusia en 1884 y su extensa vuelta al mundo de 1913. Sus testimonios son Un invierno en Rusia (1888) y Una vuelta al mundo (1914), fuentes vírgenes de todo comentario crítico. Treinta años de intensa labor intelectual separan ambos escritos de viaje, que estudiaremos detenidamente a la luz de su propia obra y de su época, en momentos en que se configura un discurso argentino sobre el Oriente - autónomo del modelo europeo-, y que dicho discurso contribuye a modelar un proyecto de Estado liberal moderno para la Nación. Este período abarca los años que van de la federalización de la ciudad de Buenos Aires (con la fundación de la ciudad de La Plata en 1882, nueva sede del gobierno provincial) hasta la Argentina opulenta y confiada del Centenario (1910).

PALABRAS CLAVE: Ernesto Quesada; positivismo; cosmopolitismo; viajes; Rusia; Oriente

Copyright: (C) 2012 CSIC. This is an open-access article distributed under the terms of the Creative Commons AttributionNon Commercial (by-nc) Spain 3.0 License. 
It is important (...) to have a look at Quesada's viewpoint to find his intellectual approach. This approach is aimed at the accumulation of knowledge as a backup for his intervention in social issues. (...) This is relevant for Quesada's observation of the Argentinean intellectual field where he repeatedly defends the rights of professionals over autodidacts or dilettantes, as we can see in his polemics with Groussac and Cané.

Oscar Terán, Vida intelectual en el Buenos Aires fin-desiglo 1880-1910.

Ernesto Quesada is a social scientist and his self-image comes close to the autonomy Seymour Lipset defines as the appropriate characteristic of an intellectual. This autonomy gives him an almost esthetical satisfaction, and explains most of his investigations.

Teodoro Blanco, Ernesto Quesada, sociología e historia en torno al Centenario.

\section{PRELIMINARIES}

Ernesto Quesada (1858-1934) was one of the bestknown and most prolific intellectual figures of the generation of 1890 in Argentina. He was the son of Vicente Gaspar Quesada, a renowned lawyer and diplomat of the Argentinean Confederation and, with Miguel Navarro Viola, co-editor of Buenos Aires magazine between 1863 and 1871, a publication he co-directed with Ernesto from 1881 to 1885 . From a young age, Ernesto Quesada lived and was educated in several American and European countries where his father occupied diplomatic posts, in a cultural polyglot environment. Some of these countries were Bolivia, Brazil, the United States, Mexico, Spain, Germany, Austria and Russia. Vicente G. Quesada was part of the Argentinean delegation at the first Pan-American Conference in Washington, in 1889-1890, together with Manuel Quintana and Roque Sáenz Peña. Decades afterwards, Ernesto Quesada recounted this event in detail (Quesada, 1919a). On that occasion, Argentina defended British interests ("America for the world") and was against those of North America ("America for Americans", the doctrine by James Monroe).

Besides being a historian, sociologist, professor, Germanist, lawyer, judge and publicist, Ernesto Quesada also stands out as a remarkable traveler. The latter was no minor accomplishment considering that his generation was well travelled, especially in the western world. His studies in the Old World (he went to university in Paris, Dresden, Leipzig and Berlin), led Ernesto to embark on travels that were unconventional for the habitants of Buenos Aires of that time.

Our interest in Quesada stems from the accounts of his travels that -together with his ample worksummarize the yearning of his generation to embrace the world in all its multiple expressions, with the idea that this was part of a refined cosmopolitism. This cosmopolitism was ambiguous. On one hand, it affirmed the convictions of an international elite; its members recognized and acknowledged each other in every place they visited -an excluding "us" that marginalized commoners. On the other hand, there was an intention to be different from other cosmopolitans, and attain a personal character. Indeed, Quesada's cosmopolitism was not only about clichés - even when these are recurrent in his testimonies- nor did he exclusively show a worldly bias -though his worldliness is put in sideways and flourishes in multiple passages. In Quesada's testimonies of his travels, cosmopolitism is positivist and has a utilitarian mission: his writings throw light upon aspects, countries and cultures little known by his contemporaries. Though Quesada's cultural baggage is European, he subjects it to criticism (he comes from a country of the periphery). He intends to put his observations to good use for the project of national construction in Argentina. Although this project was roughly outlined at the end of the 19th century, it still had new paths to explore and multiple institutional reforms to impart. Quesada's testimonies are representative of an intellectual generation and a key political period that begins with the federalization of the city of Buenos Aires in 1880 and culminates with the celebrations of the centenary in 1910 (which intend to consecrate the new nation vis-à-vis the outside world).

In this essay we will concern ourselves with some of these testimonies, especially his voyage through tsarist Russia in 1884 and his extensive travel around the world in 1913. Our sources are two somewhat forgotten texts of his voluminous oeuvre that have never been submitted to critical review. These are A winter in Russia (Quesada, 1888) ${ }^{1}$ and Journey Around the world (Quesada, 1914). ${ }^{2}$ We are interested in analyzing these memoirs because the first was written during his youth and the second as a mature man, when Ernesto Quesada was a recognized intellectual and part of the cultural and academic field of Buenos Aires. Thirty years of intense intellectual work separate these two writings. These decades are not only important as part of the intellectual biography of the author. They also cover the unique years between the federalization of the city of Buenos Aires (with the founding of the city of La Plata by Dardo Rocha, in 1882, as the new capital of the province) and the centenary of opulent Argentina.

This last observation is no minor detail. The decade of the 1880s marks the beginning of the consolidation of the Argentinean nation. The antagonisms of the liberal factions between 1852 and 1862 did not touch the spirit of the centenary, and there was a strong confidence in the future greatness of the nation -a nation pleased with itself. Instead of acknowledging its limits and analyzing the fragility of the nation's configuration, before 1910 the political and cultural 
elite, save exceptions, intended to perpetuate a positive and triumphant project of nation. We see an essential difference of tone between the two texts: the young Quesada reluctantly weighs up the barbaric aspects and "backward state" of the Russian people (in comparison with the modernity of other European nations), while in his journey around the world he does not hesitate to emit strict judgments about the countries he visits, expressing himself with the certainty of someone who feels he belongs to a culture at the forefront of civilization. It is important to point out the chronological difference that separates these texts (thirty years) and the added difficulty to contextualize them: the first, in 1883 , is part of the works of his youth, written at 25 years of age, though hardly to be classified as simple "travel notes"; the second, from 1913, he wrote as a mature man with a consolidated intellectual career, when he was 55 years old.

\section{DECENTRALIZATION OF EMPIRES. EXOTICISM AND BARBARIC COSMOPOLITISM}

Undoubtedly, in the 1880s Russia was a faraway exotic destination for Argentineans. Until then, few travelers from Buenos Aires had ventured outside Saint Petersburg, the capital of the tsarist empire that embodied the image of modern Russia and was a showcase for Europe, with a refined civilization that could compete with the large capitals of the Old World in almost every aspect. Quesada is aware of this: "perhaps the only value of this book is that it is the first one in which a South American has registered the impressions of his travel through the vast Russian empire" (Quesada, 1888: 6). With sociological care, the author apologizes for publishing these personal (though rarely intimate) impressions of his experience in wintry Russia, in which he tries to detail the simple life of its people. He does not have a utilitarian motivation for this travel, however, he tries to derive some benefit from his observations. He does not intend to repeat the information in guides and specialized books or to make a catalogue of the cultural riches of the country, but to express his reflections about the characteristics of human life in those latitudes. He apologizes for the abundance of statistical data, the professional sin of the positivist scientist, though he does not come close to the extremes reached by Eduardo Wilde some years afterwards (Wilde, 1892 and 1899).

We can consider exotic traveling to be a distinctive characteristic of cosmopolitism, as we saw with regard to Lucio Mansilla, Pastor Obligado and Eduardo Wilde (Gasquet, 2007: 103-202). Quesada's cosmopolitism is very different from that of Mansilla. Clearly, the first writer does not intend to entertain the reader with a rosary of events or rhetoric devices grazing on mundane frivolity. He also lacks the illustrated characteristics with romantic hinting we see in Travel to the East (Obligado, 1873), and the manic preciosity with which Wilde makes a recount of modernity in his Travels and observations (Wilde, 1892). Truthfully, Quesada's sociological positivism is more humane, but like that of his peers, it has a fondness for anecdote, which confirms him as a man of the world. The essential characteristic of cosmopolites is that they feel at home anywhere, and maintain an attitude of never losing control of the situation. In a way, the cosmopolitan is a gymnast of the world, and for this, his command of several languages is the master key. This multilingualism is the unequivocal sign of belonging to the world elite; a group with members that acknowledge each other on any latitude. Though these characteristics are to be found in Quesada's testimonies, the scientist in him is less inclined to worldliness than his contemporaries. We attribute his frugality to the fact that the traveler does not need to continuously reaffirm his social belonging, because it is evident to his readers. The preoccupation to "teach" prevails in his accounts, though the author recognizes himself as an amateur, not a specialist.

The exotic shift we see in A winter in Russia is caused by the fact that the Russian cultural sphere is not a copy of European parameters, though the tsarist empire is partially European. The chronicles and illustrations of travelers from Buenos Aires through Europe is so much established and spread in the elite that politicians and writers of the time consider it a banality and a recurring sub-genre. If Quesada's recount has some interest, it is because Russia is an eccentricity in Argentinean literary culture. Overflowing with information and pleasant in tone, the traveler tries to show his reader the Russian "local color", and recurs to inevitable topics like the autocratic character of the tsarist regime. From early on, with the generation of 1837, the South American collective consciousness associated the autocratic regime with barbarism and the East. This collective consciousness had inherited the mentality of the Enlightenment that would have a noticeable impact until Sarmiento.

We will concern ourselves below with some of these topics of social or historical emphasis, leaving anecdotes and cultural, folkloric and religious facts aside. Quesada's first observation is the variety of races, languages and religions that compose the mosaic of the Russian empire. Interest in these cultural aspects is prominent during this time, in which Russia was submerged in a process of intense changes and convulsions, both socially and economically -on a domestic level- as well as geopolitically -on an international level.

\section{AN ACCIDENTAL WITNESS. THE ROMANOVS, REFORMISM AND MODERNIZATION OF ABSOLUTISM}

Indeed, Quesada visits Russia three years after the entrenchment of the tsar Alexander III (1881-1894), 
whose father, Alexander II, was assassinated on March 13th, 1881 in an anarchist attack. From the beginning of his reign, Alexander III laid down a policy of extreme repression of the revolutionary nihilist sectors. After the reforms and modernizations of his father, this strategy represented a return to the autocratic absolutism of his grandfather Nicholas I, who relied on a generalized involvement of the secret police. Alexander III also fomented a pronounced antiSemitism. The (inexcusable) motive of the violent repression in pogroms, both physical and legislative, was that there was one Jewish revolutionary -called Gesya Gelfman- between the fifteen conspirators. The repression left at least 200 dead. $^{3}$ Official antiSemitism became the cultural and political code that, according to Traverso, "conveys all conservative tendencies" of the tsarist regime (Traverso, 1996a: 45). This anti-Semitic wave marked the beginning of Russian-Jewish emigration to west Europe and America, and gave birth to Russian Zionism (Traverso, 1996b: V y VI).

The pronounced anti-Semitism of Alexander III has little mention in Quesada's memories, though he emphasizes the repeated attacks by nihilists and their profound social causes in multiple passages of his book, in no way ever identifying with the anarchist cause. Jews appear as picturesque characters and are shown only as individuals or in small groups, never as a social stratum of Russian society marginalized by the tsarist administration. Alexander II was considered to be a great reformer and modernizer of the empire: he decreed the emancipation of servants, introduced municipal dumas (councils), simplified the penal code and judicial system -inspired by France- abolished the death penalty, etc. His son revoked almost all of his father's reforms. Regarding this brutal turn, Quesada prefers to point out that the new tsar deepens Russian industrialization. Though he sees the misery of the Russian people, he only mentions it in slightly critical statements. After comparing the infinite steppe with the Argentinean pampa, he says: "Fact is that the eye gets lost looking at these infertile steppes, inhabited by peasants who, dirty and badly clothed, imply that misery must reign unmerciful amongst them" (Quesada, 1888: I, 105).

Besides the internal aspects of the Russian empire, Quesada is especially interested in the role that this monarchy -the only one that stretches from Europe to the pacific- plays in regional geopolitics, with vicissitudes that affect the destinies of the Ottoman and British empires. More than once, he points out the importance of the monarchy: "the revolution that seems imminent in Russia, its decisive role in the dismemberment of the Turkey of Europe, the fatal collision that will occur in the future with England in a dispute for central Asia (...)" (Quesada, 1888: I, 11), make Russia a peculiar object of study in the concert of nations. Russia embodied a particular alchemy of residual medieval backwardness and autocratic vertical modernization. Before his travel, Ernesto Quesada published many essays on European and international politics in the earlier versions of Buenos Aires magazine, so these geopolitical issues were not far from his interests. Later on he would also concern himself with these subjects in the South American regional context, studying the border problems with Chile (Quesada, 1895 and 1899), Paraguay (Quesada, 1902 and 1923), and the debates over doctrine with the Unites States on Pan-Americanism (Quesada, 1916 and 1919b), etc. He also follows the conflicts in the old continent up close, especially during World War I, siding with Germany and opposing the British imperial strategy (Quesada, 1915a). ${ }^{4}$ Quesada was not particularly Francophile nor Anglophile, but he had predilection for the Prussian intellectual model and was inspired by the model of the Wilhelm University (Quesada, 1910). He was of the opinion that Prussia was at the forefront of scientific, historic and philosophical production, and the most complete embodiment of the inheritance of humanism and positivist Enlightenment (Bujaldón de Esteves, 2006: 47-61). Quesada points out repeatedly that the Romanovs tried to import the Prussian model in Russia at the end of the 19th century, copying the industrial, cultural, scientific and educational organization imposed by the Kaiser. The teaching of France lost prestige in Russia after the advent of the Third Republic (1870) due to fragility of the institutions after the fall of the monarchy in 1789 that was followed by six regimes in 80 years. "The fact is that Germanic influence is taking the place of French influence, and dominating Russia more and more", he states (Quesada, 1888: I, $175)$, though he presumes that this stunning Germanization goes against the shimmer of the Russian nation. Despite its immense problems, Quesada has trust in the historical destiny of Russia: "It is the Slavic race," he states, "that now disputes the scepter of civilization with Germany, previously snatched from the Latin culture" (Quesada, 1888: I, 11).

After arriving in Russia through Lithuania, the traveler emphasizes the interest of that country's literature in comparison to that of the great European nations. The "literature of that race is one of the most attractive ones", considering, as Michelet remembers dramatically, "it is sad like that of a people in agony" (Quesada, 1888: I, 96). However, the Russian institutions have to evolve urgently to get out of their backward state. "They need to be transformed so they will not be torn apart violently" (Quesada 1888: I, 187-198); this indicates that the party of the revolution was discredited after the assassination of Alexander II. He points out that the finances of the empire are so complicated that they are similar to "that of a South American republic" (Quesada, 1888: I, 200-201). The initiatives agreed on to improve superior education and scientific activity, place Russia on the same level as other west European nations. Quesada reveals the broad fissures under the tsarist 
power; a divided society where the extreme economic and scientific modernization did not lead to a political and institutional modernization. The social reality of the empire persistently maintained a duality that harbored different and even opposed worlds (decades later, Trotsky will define this as the concept of "unequal and combined development"). In his way, Quesada referred to the same phenomenon when he arrived in Moscow and his observations went beyond mere folklore: "In one word: besides the palace, a hut; close to a superb street an alley that looks like a medieval coupe-gorge; sometimes one believes to be in Europe, sometimes in Asia; at times western civilization seems to dominate, but instantly the Russian customs prevail, without the least attenuation" (Quesada, 1888: II, 25). Though he has trust in the destiny of greatness of the Russians, he is aware that the empire can fall into anarchy if the state and the social condition of the lower classes is not modernized. After detailing the new scientific, cultural and university institutions of Saint Petersburg, he concludes that "these data reveal the profound imbalance between the different social classes of Russia" (Quesada, 1888: I, 227).

Quesada points out that the traveler can spend a lifetime exploring and visiting the riches the city offers; there is an ostentatious accumulation of treasures, museums, specialized libraries and academic institutes in the capital. He utters, as a conclusion: "the traveler envies the happiness of those that live in these great cities and have the treasures to cultivate their spirit so close at hand, even without spending nights at studying soirees, just by uniting utile cum dulci. When will we be able to boast about something like that in South America?" (Quesada, 1888: I, 237). The young intellectual from Buenos Aires is far away from the confidence that will predominate in the Argentinean elite in the decades to come. He knows that the modernization of his country is under construction and that no one can guarantee the end of disputes between liberals; at that moment the political scene in Argentina was exacerbated with the debate about education between Catholics and seculars. There was still a long way to go before the centenary and the secure, self-triumphant tone that defined this period.

If Saint Petersburg is the cultured and European face of Russia, Moscow is definitely a Babel-like city, an intersection between east and west. A place of confluence of wild peoples and merchants, who are only united by their mutual fidelity to the tsar. "A uniform mix of races, civilizations, religions and customs; more than any other European city, Moscow is the contemporary Babel. But, above this incredible chaos there is always one race, one civilization, one religion: the legitimate Russia" (Quesada, 1888: II, 26-27). For Quesada the Russian civilization is, strictly speaking, not the cosmopolitan Babel, but an exclusive symbol of the Slavic civilization. To his regret, multi-ethnicity and multiculturalism are the elements that make Moscow similar to America. The geographical and racial excesses distance Russia from Europe and bring it closer to the reality of America. That is why Quesada scrutinizes this design of greatness that distinguishes it from the nations of the Old World. With all its tensions and contradictions, he sees Russia as a promise, an absolute potential more than a concrete reality:

"Russia marches in the name of the Slavic race, to
snatch the banner of progress from the united hands of
Latin Americans and Germans, just like America is
headed -with the same objective and in the opposite way-
to obtain the same purpose. Thus, the day is not far away
that the destinies of Russia and America will have more
interest to one another than those the Germanic and Latin
American nations currently have among them. Certainly,
this future still seems remote, but history already shows
the unequivocal path to convergence of these entities"
(Quesada, 1888: II, 29-30).

This positivist vision of historical progress, intuitive in character and not devoid of teleological mysticism, turned out to be quite premonitory in the light of the events of the 20th century after the Russian revolution. But the underlying tensions in Russian society made this progress a very difficult task; the extreme social polarization made it impossible to channel the traditional proclivity to patriotic panSlavism of the tsarist elites (one of their historical political slogans) towards European projection. As Quesada explains, these pan Slavic aspirations -though pretexts for regional wars (for example, the attack against Turkey in 1887 by Bulgarian Slavs)- always had little impact for two reasons: a) the governing elite always looked, praised and zealously copied the hegemonic models of the west (France, England, Germany), and would not embark on an authentic pan Slavic strategy; b) the popular classes, submerged in the dark misery of daily subsistence, scorned the warrior aspirations needed for such a regional policy. The traveler displays the weaknesses of the Russian "national spirit", synthetized in the following passage:

"In this vast empire, the races that live far from the center have little connection with the national spirit; the mass of the people, used to the secular yoke of the glebe, is indifferent to the destinies of the country. These destinies are exclusively in the hands of the upper classes; besides being a minority, these classes have the great inconvenience that since long ago they profess disdain for national things and a particular attachment to everything foreign.

That is why modern Russian history is largely only the muffled echo of the influence of other European countries. In the whole country, the upper classes are more French than Russian; administration, commerce 
and teaching is more German than Russian; in one word, everything is made foreign in Russia. What is the result of this? That the whole administrative organization, legislation, and reforms in ministries (...) are alien to the nature of the nation" (Quesada, 1888: II, 127-128).

In the final chapter of his travel memoirs -"from Moscow to Kursk"- Quesada records in many pages the vicious mechanism of the social and political corruption of the tsarist autocratic regime. This corruption is quintessential to the regime's internal dissolution (a bigger threat in comparison with the unlikely hypothesis of external aggressions). As in all his other social and political observations, the traveler abides to what he sees in cities and the countryside with great sharpness and many details. From these observations, of great preciosity, one can conclude that Russia is at a social impasse -if not desperate, at least somber. The distinct pessimism of reality contrasts categorically with the repeated confidence Quesada expresses with regard to the destiny of greatness that awaits the empire, which we ascribe to his sensibility, conviction and hypertrophied intuition. This is not the place to go into detail about Quesada's arguments. But we do emphasize the importance these observations have for the local environment of Argentina. In these six hundred pages there is a series of coincidences between western Russia and the Argentinean nation: a) the immensity of the territory, with little demographic density and large estates; b) an unsurpassable abysm between rural and urban reality on all levels; c) the oppressive inheritance from the past, that makes it difficult to implement a genuine project of a modern and/or reformist civilization; d) the difficulties to find an original path for construction of the nation. The echo of these parallelisms, saving the distances between the political models, is more pressing at the end of the book. That is why when Quesada talks about Russia, he tacitly expresses his doubts about the project of the Argentinean nation.

From the point of view of Argentinean readers, some statements act as a clear indication to take sides on a local scale. We know that Quesada had affinities with Juan B. Alberdi, whom he frequented in Europe. He clearly takes sides in favor of Alberdi's thesis and against that of Sarmiento, when he states the following as one of his conclusions: observations in Russia "once again prove the exactitude of the eternal truth that institutions aren't to be found in laws but in customs". However, this truth, old as the world, is always violated even by those who claim to see everything clearly" (Quesada, 1888: II, 347). How to modernize miserable people who have customs that oppose their incorporation to civic and political life?

\footnotetext{
"It is the masses -Quesada says- that lack the indispensable civic instruction, it is the customs and traditions that lack in the urban classes, it is the profound
}

discourage and disenchantment that has produced the vociferous failure of an initiative made in good faith. (...) It is illogical to suppose that radical reforms can be introduced with simple decrees, or extremely advanced institutions can be established when they not only clash with customs and traditions, but the masses also lack the most elemental preparation to take advantage of them. Not one all-powerful ukase of the autocratic tsar has been able to attain that miracle" (Quesada, 1888: II, 149-150)

Quesada states that Russia must implement a series of profound reform projects on an institutional, tax, civic and educational level. He considers that the authorities must work hard to introduce these reforms urgently. They are the only alternative; not only to definitely modernize the tsarist empire, but also to avoid the painful consequences of a nihilist revolution that by then was about to happen, more so than the Bolshevik threat. Quesada has no sympathy for the anarchist sectors, but he knows that the popular misery on which these revolutionaries build their strategy is not unfounded. For him, an assiduous defender of liberal ideas, raising the abstract slogans of liberalism against the tsarist autocratic regime is not only sterile in the political plane, it is also morally unfair. "What free country," he asks, "save honorable exceptions, believes it has the right to throw the first Stone in Russia?" And here we would like to know, posthumously, which ones are those "honorable exceptions" Quesada is thinking of. He then continues his argumentation in the direction previously mentioned, that reforms can only be constructed while improving the customs of the Russian population. All strategies aimed at putting an end to the historical autocratic regime with decrees and theoretical slogans are destined to fail, according to Quesada. His final position is worthy of consideration and coherent in the light of the biggest obsession the traveler and the men of his generation had: to avoid chaos and anarchy at any price. As a sociologist, Quesada thinks that social disintegration (social anomaly) can never be a winning strategy, either in the short or long term. He trusts in the future of greatness that awaits the empire, though this trust relies on intuition and the trick of belief. "Russia," he sentences, "can await the future with confidence: the unexploited riches of its soil and the many healthy customs of its peoples guarantee a brilliant future" (Quesada, 1888: II, 350). Beyond the irrefutable despotism it is known for, the Russian empire gives exemplary lessons to the west: "But even with all of the defects it has today, some extremely enlightened nations that believe the remedy to their problems is simply to increment the number of liberal institutions, could learn so much from Russia, a country that is generally seen as the typical example of absolute sovereignty! ..." (Quesada, 1888: II, 351).

Quesada concludes his travel memoirs with these words, and leaves pending some of the parallelisms 
and convictions that could be established with the liberal model of Argentina and other nations. As this travel diary through Russia is a work of his youth, we will try to complete some of his unanswered questions with the testimony of his travel around the world, written by him at a more mature age.

\section{THE POSITIVIST TRAVEL: BEHIND THE SCENES OF CIVILIZATION}

The testimony given by Quesada in Journey around the world is at the same time perfunctory and synthetic. Indeed, it is a concise document of about 80 pages that synthetizes his journey around the world in 1913. Of course, in that time these deeds were nothing exceptional, though they were limited to a reduced portion of eminent international tourists. Travels like that were not available to any regular traveler.

Let's look at a few elements, to put this journey in the right context. Given the magnitude of circumnavigation, the extension of its documentation is reduced and the author can only tackle general aspects of the country he visits, or, when he gets into detail, he does it without beating around the bush, aiming for the essentials. Quesada makes this journey in company of his wife, though she remains in the shadows of his account. This is all the more surprising because his narrative is purely colloquial. It is really a conference given at The National Council of Women on May 27th, 1914. This is not the first time that Quesada gives a speech before this same audience, but we see that he adjusts his account to the female public in several aspects: a) it is a pleasant account, touristic in tone that avoids distasteful anecdotes and seeks to seduce the auditorium with signs of flattering complicity. For this, he gives many comments he thinks are interesting to the female listeners, like references to the beauty of women in the countries he visited, women's social condition, and especially local customs; b) his speech tries to capture the audience's attention with exaggerated turns of phrase, that insist on the local atmosphere and are less informative; the analysis of peoples and countries is mainly inexistent; c) the topics of his speech are often clichés; their lack of information indicate his doubtful appreciation of the female audience; in fact, it is not an account aimed at specialists or academics, but at the general public, with no other pretension than that of pleasant "entertainment".

We do not know the exact dates of his voyage. Other travelers from the La Plata region had already frequented the stopovers of the journey to the east (North Africa, Palestine, India, China, and Japan). However, few travelers wore themselves out going to Oceania, or if they did, they did not leave a written testimony like Quesada. The only exception we know of is that of Carlos Agustín Aldao and his book of memoirs Around the world (1908), that had its fifth edition in 1914 (Aldao, 1914). This jurist and diplomat from Santa Fe, a friend of Julio A. Roca and plenipotentiary minister during Roca's second government (1898-1904), left recounts about some countries no other traveler from Buenos Aires had ever been before, like Siberia, Turkistan, Manchuria, Australia, New Zealand, Kenya, Uganda, Zanzibar, Mozambique, Rhodesia and South Africa. On the other hand, Quesada travels extensively through Oceania, especially through Melanesia and the German colonies of the Pacific, uncommon places for the men of his generation.

As a comparison, we see a great difference of style between the two, and also of concerns. Aldao goes through great pains to instruct us, but due to the disorganization of the account of his memories and the lack of hierarchy in the information -he mixes personal anecdotes with first class historic eventshis testimony shipwrecks in an unfertile sea of haste and amateurism. On the other hand, while Quesada only intends to "entertain" his reader, with no aspiration to analytical depth, he makes observations that imply that he has an exhaustive and erudite view of the places he visits. A follower of the evolutionist theories of Spencer, Quesada's view is similar to that of his positivist peers (Soler, 1968: 143-197), like José María Ramos Mejía, Carlos Octavio Bunge and José Ingenieros. However, Quesada did not understand evolutionist positivism like a mere adaptation of men and society to physical and biological conditions. Unlike other Argentinean positivists, Quesada never succumbed to the organicist or biologist thesis as a foundation of man's social activity, which was so fashionable at that time among the Argentinean disciples of Augusto Comte. He tried to base sociology and its methodology from a theoretical point of view, dedicating himself less to practical works of investigation (Soler, 1968: 158). Originally a lawyer, Quesada deviates from a strictly juridical positivist vision, that is, from a concept of sociology linked to penal positivism inspired on the thesis of Cesare Lombroso (like Ramos Mejía and others do). At the same time, Quesada stands out with a pure and often original view about cultures and territories never or little frequented by the minds of Buenos Aires. His voyage takes place at the dawning of World War I, an event that will lead to a strong questioning of the positivist foundations of human progress -in the La Plata region embodied by Rodolfo Rivarola(Rivarola, 1917).

Among the geopolitical consequences of World War I outside of Europe, there is the new tracing of the colonial map. Germany loses its few colonies in Africa and Oceania and is stripped of its limited commercial agencies in Asia; the Ottoman Empire is dismembered, giving way to a new colonial partition between England and France in the Near and Middle East. The travel of Quesada makes radiography of the world after the Conference of Berlin in 1885, ${ }^{5}$ just 
before the cataclysm that would change its physiognomy forever. This makes his vision of the world extra interesting.

Though the thread of his recount is defined by his condition of tourist, Quesada makes it appear in several occasions that the aim of his travel had no mundane or pleasure seeking motives. The form and content of his discourse is tailored, to his regret, to the picturesque model and informality of a "family conversation". In fact, the final mission of the traveler was to make a comparative study of property rights in several countries. The lecturer says: "I had the purpose of a technical investigation -the critical exam of property rights in specific countries- and I had to subordinate everything to that objective, and submit my globe trotter curiosity to it (...), duty forced me to that immolation" (Quesada, 1914: 6). From the material compiled during the voyage, Quesada published a study about legislation on real estate in Tunisia one year after his conference (Quesada, 1915b). This voluminous essay was more than eight hundred pages long.

\section{POSTCARDS FROM MAGHREB AND LEVANTE}

The account of Journey across the world puts European countries aside to concentrate on the exotic destinations of Maghreb, Asia, the Far East and Oceania.

The first stopover is Algeria, which is evoked with the cliché of "mysterious world of the East, (...) Arab and Muslim life, full of poetry and reverie". The first contact with Algeria arouses a series of trivial opinions for the travelers of that time: astonishment at the snowy tops of Atlas, the majestic beauty of the bay of Algiers, the "stupendous mix of Muslim life and European culture", "the closely-woven veil of exciting women whose eyes shine (...) through the archaic opening of the traditional haik", "the multicolored crowd of Jews", those city dwellers, mosaic of nationalities that "represent a complete collection of human races" (Quesada, 1914: 7).

There is also a procession of the classical topics about Arab countries: the tumultuous life in lower class neighborhoods, the Kasbah, the cafés full of regular customers smoking hookah. In short, "that Arab life, of reverie and leisure, of pleasure, of love, of all that the lustful Moorish imagination can conceive: that, that is what fascinates and dazzles" (Quesada, 1914: 8). The contrast between public and private space is also one of the characteristics that are always evoked. The hustle and bustle of the streets contrasts with the privacy of homes. Life is turned outside the house, so as to better protect the home that guards the treasure of the harem. Sensuality (in the private sphere of the home) in Arab countries is always the topic of erotic fantasies, where women hidden behind veils are spied. "Harems," he says, "never tire of receiving beauty of all types and origins" (Quesada, 1914: 8). Commonplace images accumulate; like a daydream, it is "the vision of a new world for the traveler of white race".

Another classic subject tackled by travelers in Maghreb is that of the indolence and idleness in these peoples, understood as a structural lack of will to work. Unlike the testimonies that preceded him, Quesada paints these character traits with benevolence, almost as a sign of the congenital happiness Arabs live in:

\footnotetext{
"This population seems to ignore or despise the sorrows or preoccupations of existence, and vegetates imperturbably, majestically, happy, not asking anything more of life than to live the present moment, without noticing there is a tomorrow, so great and unmoved is their faith in almighty Allah and Muhammad, his prophet!" (Quesada, 1914: 9).
}

Behind its innocent appearance, this observation is actually cunning, because it reproduces one of the most extended prejudices about the Arab-Muslim world since the Enlightenment: the idea of inaction, that time is annulled in the Arab culture by the quietness of spirit. We point out, by the way, that female sensuality is strongly linked to immobile contemplation, a quality that western travelers attribute to Arabs - and that they tacitly or explicitly oppose to the vigorous action of whites, who are considered to be the vectors of modern civilization. We know the opinions of Sarmiento about Algeria; he interpreted these same prejudices as the mark of wild and artful peoples. Wilde did more of the same, in an ideological context dominated by positivism. In keeping with his time, Quesada does not give these characteristics such a pejorative connotation. However, we easily deduce that behind this "existence free of worries" there is a paternalistic view: Arabs are naïve children that must be educated in the values of modern civilization, that is to say, the values of effort, accumulation and predictability of the future. These three vectors of civilization need to have a complex social organization and an adequate disposition and use of practical methods (scientific, technical, statistic) to make it possible. The term "vegetates imperturbably" presupposes a homogenous temporality where present is fused with the past, because the future is also a constant repetition of the past. The imperturbable faith in the prophet that encourages the Muslim believer is, in this logic, a guarantee of immobilism and practical indolence, because they both rely on a flat notion of time. Belief without questioning is evidence of the indolent character of these peoples. We can see that, behind the indulgent tone of Quesada, there lurks and sticks out ferocious criticism. There is only a fragile barrier between enthusiasm and criticism of the natives. 
Quesada's passing through Tunisia is intense. He is especially interested in the Arabic neighborhoods (El-Medina) and the souks of the capital (in his opinion, more intense than those of Cairo and Istanbul). There is a special section on the visit to the ruins of Cartago, testimony of the ancient civilization that used to exist in these Berbers lands. For Quesada, the novel Salammbô by Flaubert synthetizes the rich Punic antiquity and the posterior superposition of cultures and religions. For an evolutionist and follower of Spencer like Quesada, the French protectorate is another step in the historical progress in those latitudes: "a small area of earth that encloses the most interesting ruins of history, the most curious testimony of Muslim culture and the most eloquent proof of power of current European civilization" (Quesada, 1914: 12). Ancient native urbanism, the labyrinth of medieval alleys of the Kasbah, is slowly substituted by a modern European tracing with the creation of parks, boulevards, sanitary works and new neighborhoods.

The excursion to Egypt leads him to evoke some other classical topics of western travelers in the ancient lands of the Pharaohs. Cosmopolitism of the modern cities of Alexandria and Port Said, its contrast with ancestral tradition embodied by El Cairo, the historical remnants of Heliopolis and Upper Nile States. The general impression of all these cities is the typical Babel-like representation of social life, with the most varied mix of races, cultures, religions and languages. Quesada mentions that his dragoman (guide and tourist translator), called Raschid Monthani, "thought I would be interested in something most are not much attracted to: the intimate aspect of Egyptian life" (Quesada, 1914: 15). For this reason, he takes him to meet a Coptic family (the old Christians of Egypt), to witness the celebrations of baptism, a marriage and the procession of the bride, a Muslim funeral. The traveler is also taken to a zirk, a Sufi celebration of the dancing dervishes that get into hypnosis reciting prayers while they dance. He sees the sumptuous celebration of the White Carpet, performed by pilgrims who return from Mecca, and also the procession of Hussain and Hassan, that lasts ten days, in which believers in trance flagellate themselves with scimitars in a display of public martyrdom.

More than these particular testimonies, for Quesada the most notable aspect is the fantastical existence a tourist lives in Egypt, which "makes him believe he is in the land of One thousand and one nights", as if this work were a compendium of cultural anthropology and synthesis of the Muslim world and not just a literary reference. For the traveler, it is as if the descriptive of One thousand and one nights embodies the existence of a world of paroxysmal contrasts: "next to the picturesque spectacle of indigenous life in Egyptian, Coptic or Muslim neighborhoods, lives elegance, lavish and full of shine; and that same extraordinary contrast of shine and beauty has a very intense effect, difficult to exceed in any other part of the world" (Quesada, 1914: 17). In lands where a new hybrid and colonial civilization sticks out over the ruins of the civilizations that preceded it, multifaceted Egypt seems to the tourist to be the embodiment of pure cosmopolitan spirit. Quesada does not say anything about the budding Egyptian nationalist party that takes form in those years of British rule. On the other hand, he remembers an anecdote in Karnak (a concession to his listeners?) in which the enchantment of the valley of Thebes is broken when a group of tourists, exulted by the ruins, starts to dance the tango under the rhythm of an improvised orchestra. He then expresses the epithet: "that dancing pest that seems to have invaded the contemporary chic world as another fleeting fashion! It was a true sacrilege; it threw the enchantment of the place to the ground" (Quesada, 1914: 20)

In Palestine, still under Turkish dominion, Quesada observes in Jerusalem the merciless combat of intrigues the European potencies embark on: "under the cloak of religion, every nation fights for a tangible political influence, with eyes on the announced dismemberment of the Turkish Empire: a false information that periodically travels unperturbed through all regions" (Quesada, 1914: 25). Indeed, since the 17th century, Europeans were betting on the fragmentation of the Ottoman power in the Near East, something that never happened despite the emancipation of Egypt (under the sultan Mehemet Ali) and the British occupation (1882). The Argentinean traveler could not suppose then that he was looking at the last act of this large domination, just before the Ottoman defeat after World War I. This explains his unbelief. Though it seems paradoxical, he points out that the Turkish power was the only guarantor of peace among the different Christian factions in the Holy Land, always about to embark on conflict.

Unlike the mystical evocations of Christian peregrines through Palestine, that exaggerate the beauty of the biblical landscape, Quesada confirms its poverty and misery, stressing the general sadness that prevail in Gethsemane and Mount Olive: "everything is sad there, from the scarce vegetation to the memories they evoke; however, that hill resumes all the last days of Jesus"(Quesada, 1914: 25). Outside of Jerusalem, the Palestinian villages seem immobile, as if time has stood still in two millennia. About Belen, he says that "it doesn't seem like 2000 years have passed". He feels sympathy towards the backwardness the population lives in, because he interprets it as a rare survival of past times: "I was in awe (...) when I saw the inhabitants that are of the same race, unmixed with others, as those in the Bible; women are always dressed in the classical garments of Judith" (Quesada, 1914: 26). He says the same about the traditions he sees in Nazareth, where women go through steep streets with a pitcher on their heads, acquiring 
"slenderness and a majestic and elegant trait". The "beauty and seduction" of these women is imponderable (Quesada, 1914: 27).

\section{INDIA IN FILIGREE}

The Indian course leads him from Bombay through North India to Madras, passing through Agra, Delhi, Benares, Darjeeling and Calcutta. At Madura he embarks to Ceylon (currently Sri Lanka). His change of tone and disposition is notable in comparison with Muslim countries. Quesada faces the Indian subcontinent with benevolence and humility, and highlights that even for a sociologist it has a complex and fascinating character. According to him, this complexity is the country's main advantage. "I was living my lifelong dream," he confesses, "and for years I had tried to accumulate all the information books could give me about that wonderful country, overflowing with attraction and mysteries, and surrounded by light" (Quesada, 1914: 29). The contrasts and "peculiarities of its life" are difficult to discern at first view for the South American traveler, inexpert on these geographies.

It is worthwhile to insist on Quesada's change of attitude. Until the end of the 19th century, India was an abstract territory; travelers from Buenos Aires that had ventured there were intellectually unarmed to understand it. The exclusively frivolous and superficial view of Mansilla (during his stay in 1848-1849), or the brief stay of Wilde (in passing to Ceylon), did not go very deeply into this jewel of the British crown. Though ignorance still reigned at the beginning of the 20 th century, by then there had been a fundamental change: these latitudes benefited from a spiritual current that was popular in important segments of the western intelligentsia. During the second half of the 19th century, important studies had started to decipher the complex history, philosophies, cultures and religions of the subcontinent, and part of its classical literature was slowly becoming accessible to the public.

Among Argentineans, the extensive description by Lucio Vicente López about the Ramayana in Buenos Aires magazine (Vicente López, 1869a and 1869b) was a precursor of the growing interest of cultured men in those cultures and cosmogonies. Though Ernesto Quesada was a child by then, he undoubtedly knew later on of López's effort to disseminate the virtues of classical Indian literature in the La Plata region, as his father was one of the magazine's codirectors. In this work, López refers to the recent French and Italian editions of the Ramayana, and to prove his great literary quality, he translates extensive passages to Spanish. López is aware of the novelty of this work in the La Plata region and the west: "it will seem strange that our spirit dwells (...) on the study of a work that is completely unknown for Latin America (and that is also) new in the literary centers of civilized Europe" (López, 1869a: 208). His aim is to give Argentinean readers a first approach to the work, comparing it to some of the universal classics of universal poetry, like Homer's Odyssey, Virgil's Aeneid, Milton's epic poem Paradise lost, or the poetry of Ossian. López insists it is a "monument" of universal literature, calling it an "ocean of beauty". "The poetry of Ramayana is like the poetry of infinity" he states, "more profound, vaster, more intimate than the poetry of Homer. (...) The Ramayana is like the sketch of a great painting, full of bold ideas, and intention in the plan" (López, 1869a: 213). López ends his review with a call to translate this Sanskrit work to Spanish and insists on the unequivocal fact that it is a major work: "Because of its sublimity, the Ramayana is destined to stand next to the first epic poems of antiquity that made Greece immortal, and that are nowadays the literary models all creations of the human spirit converge on" (López, 1869b: 427).

In the Argentinean context, the pantheism of Ramayana is also combined with the traditional spiritualism (Roig, 1972) of a large part of the intellectuals of the turn of the century, like Joaquín V. González (Gasquet, 2013), whom Quesada frequented in the La Plata University. There is a new generation of writers interested in eastern literature linked to Nosotros magazine, in which Quesada published, just like Álvaro Melian Lafinur and Carlos Muzzio Sáenz-Peña. The latter played a fundamental role promoting classical eastern literature in Argentina; he was one of the first translator of the Rubaiyatas by Omar Khayyam (Gasquet, 2012), an expert in Persian and Arabic poetry, and translator of Rabindranath Tagore. While Quesada took his trip around the world, the popular Bengali bard was the first Asiatic writer to receive the Nobel Prize in literature in 1913. These elements centered Quesada's interest in Indian culture and civilization.

Bombay is the great Cosmopolis of India and the sea is its entrance. Quesada is enraptured with the city's charms, despite the labyrinths of streets, dirty and "crammed with people". The traveler sees poetry in the maritime coastline and its urbanism, the promenade that surrounds Malabar Hill, the spiritual retreat of its Hanging Gardens, "which gives quality and lineage to both Indian and European aspects" (Quesada, 1914: 29). Bombay is a metropolis of superlatives, always contrasting, pressing, but plainly seductive to the visitor: "That city enchants, because in it there is a divine mix of the most refined European life and the most characteristic Indian existence: splendor and misery rub shoulders incessantly" (Quesada, 1914: 29-30). The city contains the two faces of Janus, represented by the luxurious mundane passages of White Street, with its pompous arrogance and unusual display, next to Black Street, where prostitution is practiced without shame or scruples. India is not just a mosaic of races and religions, it is 
also a mosaic of castes. Out of the jumble of all these characteristics there is a certain generalized lack of concern among its habitants. According to Quesada, Indian culture is summed up in a trilogy that is the fundament of the social existence of the country and the entire East: kismet, doostor and backchiss. In his own words:

\footnotetext{
"Everywhere, the majestic calm of the conscience of kismet, fate -that with doostor, customs and backchiss, perpetual gratuity, seem to constitute the trilogy of the East- engrave and print a special air on the inhabitants, a thousand leagues removed from the feverish toil of people in a North American city of the busyness of passers-by in any European metropolis" (Quesada, 1914: 30).
}

The result of this basic combination is that Hindis, with some exception -like the Farsi- are not much prone to diligent action. This parsimony that seems to stretch the notion of time to infinity, in reality annuls it completely. As Quesada states: "time does not exist for the Hindu, and his feet are too heavy to take a step, so he practices laziness" (Quesada, 1914: 30). Unlike other countries, the Hindu slowness has little to do with idleness. On the contrary, it is an essential component of efficiency and the expression of its high culture. As irrefutable proof of this, Quesada points out the multiple architectural wonders of the nation: the Taj Mahal, the ruins of the ancient capital Fatehpur Sikri, the mosque of the Pearl, etc. The brilliant mausoleum of the Taj, in honor of the deceased Mumtaz Mahal, is according to the traveler the embodiment "of the most intense, absolute and captivating love". This jewel of universal architecture is superlative and unparalleled; it is "free of any competition" (Quesada, 1914: 33). It is a funerary song to life and love, and not a celebration of death. Visiting it is worthy of a trip to India.

Quesada's admiration for Hindu culture has contrasting aspects. The monuments that celebrate the past are also glaring proof of the social injustices of that past. Only the extreme misery of the populace could conceive these buildings, which are a result of crass despotism. That is why Quesada goes over the classical topic of eastern travel: absolutism or the reign of arbitrariness. These treasures "are the result of an art that will never be repeated, because it requires the crude despotism of past times, that mercilessly drinks the blood of its subjects and harasses the people excessively, because the sovereign reigns in his own interest according to his whims" (Quesada, 1914: 35). In reality, the evocation of historical despotism in India, gives the traveler the chance to point out the main sociological cause of the ills of the present: the intransigent social organization of castes. Delhi, administrative capital of the British colony, is not an open and welcoming city for the foreign visitor, but on the contrary, a bulwark of native traditionalism. In its streets, the ferenghis (foreigners) can see how women are marginalized. According to secular tradition, the upper classes live in absolute seclusion (state of purdah) and the occasional traveler can only see the lower classes and untouchables in public.

Quesada makes special mention about the civilizing enterprise of the British. Unlike other inhabitants from Buenos Aires who preceded him (who were openly anglophiles and celebrated the modernizing capacity of the children of Albion), our traveler makes a less optimistic balance, though more incisive and thought provoking. Quesada observes an "indomitable passive resistance" from the Hindus, whose religious beliefs are infertile for any intent of religious syncretism and/or cultural intermingling. "The diverse Hindu races," he reasons, "are absolutely opposed to temper the excesses of an innovation in their religious concepts, and these do not allow them to fuse with the European, nor to replace some things with others, unlike the Muslims, Farsi or other beliefs". The Hindu spirituality makes them definitely resistant to material progress. "The result is that British domination, which has civilized the country materially with the introduction of European progresses and colossal public works, is really superficial and does not respond to the obligations of its office, as it does not exert a true influence in the millions of the indigenous Hindu masses, on which it trickles like water on crystal, without leaving any trace at all" (Quesada, 1914: 36).

The traditional figure of the drogman (guide and translator) in all the eastern travelers since the 17th century is embodied in India by the colonial boy. For travelers from the west who were more or less wealthy, it was common to go with a small entourage of servants, as Lucio V. Mansilla explains. Quesada's retinue was actually a little smaller, but he quickly gets used to the comfort of this type of services. He explains its usefulness: "Every traveler goes with his boy, an especially trained indigenous servant, who serves as translator, watches out for him, anticipates all his desires, prepares his bed, brings him his tea: in short, becomes an admirable and irreplaceable valet. One cannot peregrinate through that country without taking a boy at the moment of setting foot in India, and the boy is kept until the moment we get on the steamboat that takes us away from its coasts. (...) It is not strange, then, that with such a lifestyle, whoever has lived in India dreams of going back" (Quesada, 1914: 37).

This variation of the drogman is more versatile, because in addition to being a guide and translator, the boy is mainly a rental servant, who solves all problems of daily life. The culture of services that in Arab countries and the Ottoman Empire was embodied by several natives (the drogman was only one of them), in India is concentrated in the boy, the true "valet". Quesada emphasizes contradictory aspects of secular modernization: on one hand, he observes that the British civilizing enterprise does not penetrate in 
Hindu society, but he approves of the residue of traditional service. The journey goes on through Benares, the buttresses of the Himalaya, Darjeeling and the tropical valley of Terai, Calcutta, Madras and Madura, with cosmopolitan encounters in every stopover. As in the 19th century, cosmopolitism is neither related to social homogeneity nor to the democratic character of the countries that are visited. On the contrary, it is an elitist cosmopolitism, highly selective, of a group of international, usually polyglot travelers that assume that social inequality persists. This cosmopolite mark contains certain colonial habits. Even while Argentinean travelers criticize certain aspects of European colonialism, they undoubtedly feel flattered by their beneficial collateral aspects, like the comfortable service of the boys.

\section{SPIRITUALITY, THEOSOPHY AND COLONIAL PARADISES}

While passing through Benares, Quesada makes an observation that, seen from afar, shows a notable change from the travelers of Buenos Aires in the East. Towards the centenary, the great Asian nations are envisaged as new centers of philosophical and spiritual influence and irradiation. Those countries are no more the eternal embodiment of barbaric backwardness or the survival of despot and absolutist traditions, an image that dominated all of the 19th century. The spiritual descent of the West from the East is now evident. That is why there is a change in disposition in the traveler: from a pontificating, civilizing excursionist, he now takes on the frame of mind of the humble apprentice before a complex spiritual scene. This change is palpable with the outbreak of World War I that will put an end to the most conspicuous caprices of permanent progress in Europe. Towards 1919, the literary critic Julio Noé expresses it clearly as follows:

\footnotetext{
"In the unsettling hours before the war, during the long years of the war, and in these first moments of a new age, the mystical flame that gives more warmth than a hundred hearths and gives more light than the sun is again alight in the hearts of western men. (...) The great tragedy suffered by the world has hastened a return to mysticism. (...) Persian poetry, the Hindu legends, the old beliefs from ancient times, have for us, men of this century, an intimate and transcendent meaning that has remained undiscovered for the men of yesterday. There is no other explanation for the strange thirst some modern westerners have for drinking in the ancient springs, and their eagerness to walk the old roads and take communion with the oldest men" (Noé, 1919: 5-7).
}

It is notable that Quesada anticipates this tendency before the breakout of the world war. The return to spirituality -and often mysticism - in the West was an element already addressed by theosophists since the end of the 19th century. But that type of pan-spiritual and humanist sermon - seen in writers like Leopoldo Lugones as a defense of the paganism and poetry of Omar Khayyam (Gasquet, 2007: 222-232) - was dulled by the triumph of positivist values and the inexhaustible trust in the progress of civilization. Quesada states in relation to the spiritual gravitation of the holy city in the bank of the Ganges: "center of religious thought (...) starting from there, as a powerful intellectual nucleus, the purest doctrine and most elevated philosophy and today, by one of those curious evolutions of human mentality, contemporary philosophical thought seems to slowly turn once again towards Benares, in the form of the theosophical movement and the critical renovation of the hermetic and mysterious theory that the Sanskrit books expound" (Quesada, 1914: 42).

One cannot expect Quesada to share the theosophical doctrines ${ }^{6}$ without any major objection; however he states that this evolution towards the spiritual dimension of the East is a need of western thought. Of course, he does not find an adequate explanation for this phenomenon, which he ascribes simply to intellectual curiosity. This tendency remains unjustified, and is mainly a result of chance. Neither does he manage to identify the profound spiritual demands of many Argentinean intellectuals of the centenary. Incidentally, the positivist sociologist is seduced and touched by the spiritual demonstration of the Hindus. These statements are followed by a large amount of clichés about Benares, its celebrations and temples, the yogis and sadhus, the deplorable hygienic conditions and the social organization. Quesada tries to explain the "sublime beauty" of the Hindu religion with multiple ethnographic observations. Also, with allegories and symbols, and the mass of devotees that "reduce everything to a supreme concept", Brahma. In the outskirts of Madras, Quesada visits the suburb of Adyar, the center of the theosophical movement. The guide of that visit, a "distinguished Hindu gentleman", as a warning "informed me that that teaching (theosophy) can perhaps enliven the eyes of westerners, but will not brighten up the view of easterners" (Quesada, 1914: 47). This precaution makes Quesada confirm the idea that, despite colonial dominion, Hindu culture was impermeable to western civilization. On the contrary, theosophy was a sort of emanation of eastern spirituality that could "illuminate" the blindness of the west. Local customs and folklore, despite his abysmal incomprehension, their hybridity and "grotesque symbols" affected the traveler because of the honest faith behind it, which evoked his utmost respect. "That fervent faith," he says, "I honestly haven't seen greater, more complete or sincere in any of the most famous churches of Christianity", except in some Russian monasteries. The exuberance of the temples, dresses and jewels of the parishioners, caused "the most intense sensation of the most intense Asiatic voluptuousness" (Quesada, 1914: 48-49). As an image, the topic of eastern pomp 
is topped with the use of superlatives ("most intense of the most intense"). Quesada is intellectually unarmed before the overwhelming spiritual universe of India. That is why he resorts to the archaic reflexes of the tourist; after taking photographs of a sanyasi who pierces him with a disapproving look, Quesada feels he has committed a desecration, he feels anxious and guilty. Though he is repentant, the transgression haunts him for a long time and he confesses: "I see the strange, penetrating, incisive look, with an unexplainable glow, when I have daydreams about that place in Benares" (Quesada, 1914: 46).

In his tournée around the world, the stopover in Ceylon is a chapter full of clichés. From years gone by, the great island in the Indic Ocean was, in the amazed eyes of European travelers, the representation of a tropical heaven on earth, with all of its biblical attributes. Except that the people's religious beliefs are dominated by the Buddhist imaginary. Quesada's appreciation confirms this view: "the biblical heaven on earth" he says, "was located on the island of Ceylon" (Quesada, 1914: 51). The city of Colombo has the charms of colonial life, and is a splendid winter residence on that latitude. It is enlivened by British urbanism, a sign of the highest cosmopolitism, "undoubtedly sumptuous because it is sponsored by the most demanding tourists" (Quesada, 1914: 51), so as to enjoy the happiness of the "eternal spring" of the island. The traveler makes an excursion to the ancient indigenous capital, Kandy, in the center of the island and in the hills. There he visits the temple of Dadlada Maligawa that harbors a famous relic, the sacred tooth of Buddha -therefore one of the most sacred places of pilgrimage for Buddhists. Quesada emphasizes the exotic sphere, the folklore of local colors, and the vociferous and theatrical monastic activities.

Before going to the countries of the Far East, Quesada visits Australia and New Zealand, countries he does not want to refer to in this occasion because he has already done it in his university classroom and because he considers they do not essentially belong to the East -except for their geographical locationbut to the European cultures overseas. A passionate Germanist, he explores the German colonies of the Pacific for some time in Melanesia, the archipelago of Bismarck (Papuasia and Salomon Islands), New Guinea and Carolina Islands. He is full of admiration for the handful of Teutonic colonists, who embarked on the adventure of civilizing these far away insular lands that are diametrically opposed from their land of birth, fighting against the hostility of nature and humans.

Though these colonial experiments are fragile and unstable, Quesada points out the inexorable triumph of civilization over wild cultures. He sees a "colonial love affair" that overshadows the social differences between colonists and natives. In those lands where wild life prevails, "it is admirable to see this handful of (white) men, resolved to slowly transform these places, cautiously advancing inwards, carefully organizing valuable plantations (...). But the Germans, who came last in the distribution of the world, have had to take what other nations rejected before, and build their colonial empire with admirable persistence on weak foundations; despite all pains, they fight vigorously against every obstacle, make their conquests and embark on their tasks. One has to visit these sites to understand how heroic the struggle is (...) of those "protectors of civilization" (Quesada, 1914: 57). Quesada stresses the colonial circumstances that will allow, shortly, for the existence of a new "mixed race that will be more European than indigenous" (Quesada, 1914: 57).

\section{PHILIPPINES, CHINA AND KOREA}

His visit to the Philippine archipelago allows Quesada to observe the only eastern society constantly molded by European colonialism and Catholicism since the 16th century. The splendid historical old quarter of Manila, of Spanish imprint, contrasts with the growing cosmopolitism of the modern city, that contains a mix "of Chinese, quite a few Hindus, Singhalese and people from diverse parts of the East", and the different Philippine classes, "from the tao of the forests to the illustrated upper class". This crowd of passersby that fill the streets seems like "a real cinema representation, for the huge variety of human types that incessantly goes there on their way" (Quesada, 1914: 58). The spectacle of the ancient colonial society, with its dazzling colors and traditional attractions, contrasts with the mark the United States left there since 1898. The impact of the new colonial power leaves its first traces in urbanism and the obsession with medical prevention: "North American sanitary changes have been successful in their ambitious pretention, creating beautiful modern neighborhoods with clubs, hospitals and a superb hotel in the Luneta Place". Among the large number of public works built by North Americans, roadways stand out: "which is wonderful," Quesada states. "Thanks to the efficiency of the current regime that has spared no expenses to build it, the network of highway roads make it possible to go through large part of the island of Luzon by automobile with such ease that not even those of France or Britain, that are so carefully looked after, compare to them" (Quesada, 1914: 59).

The British possession of Hong Kong is the springing board for his visit to continental China. Quesada's passing through the island is brief, but he has an experience there that is exemplary and instructive about the "true" character of the Far East and China in particular -a political despotism that exerts its discretional power thanks to the social indifference of the silent masses. Arbitrariness of power and popular anesthesia are two faces of the same coin. Besides modern commerce and the buildings of the British, Hong-Kong dazzles the traveler with its traditional Chinese neighborhoods. In these, 
Quesada observes the subsistence of public execution; in the middle of the street, "by way of lesson, Chinese thieves or criminals on the floor, with feet and hands in stocks and a sign with Chinese characters on their chest: behind them, a Sikh soldier represents the British authority that imposes the penalty and executes it in a public place" (Quesada, 1914: 60-61). Spectators, mostly Chinese, gathered in front of the condemned "looked at the spectacle with the indifferent eye of whom is used to it from his childhood on, regardless of the weight of the judge's hand". And as a conclusion, the Argentinean says: "this was my first impression of the Chinese regime and my eyes didn't tire to look at it, considering a European government had adopted this procedure" (Quesada, 1914: 61). This anecdote shows the character of every colonial power: foreign civilization adapting to local customs, as the only way to sustain a secular power. The European government, tacitly identified with civilization, must adopt proceedings of the native Chinese people, tacitly identified with barbarism, as an effective strategy to sustain domination. According to the traveler, the three clichés that synthetize Chinese society are: public lessons, palanquins and rickshaws (of human traction). These traditions are an example of societies that are resistant to western modernism, with a social hierarchy that excludes social mobility as a means of transmission between the classes.

The course through China passes the cities of Canton and Shanghai, Nanking, navigation on Yangtze towards Hankau, and finally Beijing, and then via Mukden (in Manchuria) to the Korean peninsula. From this visit, Quesada points out some distinctive signs of the process of modernization, like the gradual disappearance of braids in men, especially in cities, and the then recent prohibition of foot binding in women, that caused deformation and extreme stiffness and were considered beautiful. Besides these social aspects, Quesada finds almost all elements of modernity in the European enclaves or in the neighborhoods of the western legations of the capital. He spares no superlatives to describe life in Shanghai as one of the "most beautiful places in the whole world". The architectural richness of the European areas is a result of international emulation: the maritime street of Bund, the promenade of Wampoó, Maloó Avenue, the luxurious Foochow Boulevard, etc. There is no collection of buildings so harmonic "in Europe itself" (Quesada, 1914: 63); these are exclusively to be found in this overseas West, a counter of multinational commerce immersed in the heart of the Far East. "Shanghai is a place where one longs to live," he says, "so magnificent is the city and so refined is existence in it. Of course, next to the European area there is Chinatown, with its labyrinth of streets that reproduce the unforgettable impression of Canton" (Quesada, 1914: 64).
In Nankin, with a student as guide, Quesada observes the numerous ruins left by the Taiping rebellion -that destroyed the city between 1851 and 1864- and the last republican revolution (1911) that established an interim government in this city. Traversing the "yellow plains" to win Beijing, Quesada observes that the political confrontation between republicans (in the south, supporting the reformist Sun-Yatsen) and partisans of the empire (in the north, supporters of president Yuan-Shikai) had become part of the campaign and led to a generalized political discontent that "drove everyone crazy". This discontent would lead to the bloody civil wars of the next decades. The dispossessed population travels by train as stowaways on the roofs of wagons, and many die every day when they fall off. The Chinese are indifferent to these tragedies, and show stoicism when faced with pain and have an immense disdain for life: "nobody worried about this, because the population was so large and disdain for life so absolute, that it was not considered to be important (...) I don't know if they overcome pain with reason, but they prove to be completely indifferent" (Quesada, 1914: 68-69).

Beijing is described as "the most interesting city in the whole universe", undoubtedly not only for the richness of its history, but also for the immense contrasts it has in modern times. These contrasts are to be seen in urbanism, with the old imperial city or the Forbidden City, and the profane districts. Another dimension of this is the abysmal difference that separates the neighborhoods of foreign legations from the Chinese lower class areas. This urban sociology reveals "the secret of a regime that is stumbling with the new state of things". The visit to the summer palace makes him reflect on the vacuity of power and the ephemeral character of empires: "there, one can daydream about the fleetingness of the world's grandeur, now that there is no trace left of this age-old empire that had a dynasty that seemed unmovable just a few years ago" (Quesada, 1914: 73). Quesada remembers this scene just like Volney once did in the ruins of Palmira when he pondered the miserable destiny reserved to empires of the past.

The passing through Korea is brief, on his way to the Japanese archipelago. Like Manchuria and Mukden after the Russian-Japanese war of 1905, the Korean peninsula was under Japanese dominion in 1913. The Korean population, "of a quiet and sad temperament, appears to be resigned to the mourning of its recent international beheading and endures patiently the yardstick of rigor'. The countryside is poor and backwards, and looks primitive. Industries are nonexistent. The palaces are abandoned and the Japanese occupation shows great apathy towards their conservation. 


\section{IN THE EMPIRE OF THE SUN}

Quesada sees his visit to Japan as the icing on the cake of his travel to the Far East. He reaches the archipelago crossing the Strait of Fusang by steamboat, to the port of Shimonoseki. From there on, the itinerary takes him through Kobe, Osaka, Kyoto, Nikko, and Tokyo and then he leaves Yokohama to Hawaii. He arrives in the middle of May, when the cherry trees bloom, one of the classical Japanese images of travelers. After a lot of bustle, Quesada finds an esthetical and spiritual calm in this country and this make it difficult for him to part: "I keep my splendorous memory of Japan like a treasure. (...) The fairytale country of the rising sun has made such an impression in my heart," he confesses, "it touches me so closely and deeply, that I could not decide to leave and only harsh duty forced me to put an end to my stay. (...) Every other memory pales when I think back to what I saw there (...); I'm left with the ardent desire to return" (Quesada, 1914: 76).

Quesada's observations largely reproduce the clichés of western travelers in Japan: the natural beauty and national cult of flowers, the importance of tradition and the enormous effort of modernization, the unequaled beauty of its women and the tea ceremony, the sublime art of living and sensuality in general, the Nô and puppet theatre, etc. Before him, Eduardo Wilde detailed these images more thoroughly, and also exhaustively revised all the modernizing elements of the social, political, educational and industrial life of the country. In comparison, Quesada's look is much more superficial. Despite this superficiality -attributed to the characteristics of his discourse and audience and the Japanese stereotypes spread by Pierre Loti (Madame Crisantemo)- Quesada tries to surpass surface observations ("one can't make do with a simple tourist excursion (...); one needs to penetrate the intimacy of customs").

For this aim, that has the added difficulty of communication via a translator, Quesada uses "the golden key of contacting persons of a certain social position, because they go out of their way to show the visitor everything" (Quesada, 1914: 77). His conclusion is unquestionable: given the strong atmosphere of seduction that regulates Japanese life, he considers "that existence superior to that of the west, with more charms, enjoyment, pleasures" (Quesada, 1914: 77). This feeling of being in a country with "superior" parameters of civilized life was common among foreigners who visited the country, to such a degree that we can consider it as another cliché of traveling to Japan. Without a doubt, this feeling was a result of the unique combination of modernity and tradition that made the Japanese empire special among the other advanced nations. The official religion of Shintoism -a local hybridization of Buddhism- widely spread among the population that special alchemy of obedience and creativity, of respect of traditions and mental freedom that strongly disconcerted international travelers. But superimposed over all this there was a more permissive (social, familiar and individual) culture in comparison with Victorian moral values, a morality that was not considered immoral but was freer and less prejudiced with regards to the western taboos of the body: a different notion of the body, a different sexual morality (which was always associated to the cliché of the geishas). That is why there is a systematical reference to pleasure and enjoyment to describe Japanese life. Adulation of young ladies' attractiveness is a constant among visitors of the archipelago ("a seduction unequaled by that of any other race, because they carry a portable heaven in their soul..." (Quesada, 1914: 77). This element, banned -as a sin- from western culture of that time, is one of the main attractions for travelers.

In Osaka and Kyoto, visits to traditional theatres, make Quesada say that one can sense "an air of true life, not to be found in European theatre" (Quesada, 1914: 78) in Japanese plays, which are based on a structure with more room for improvisation. From this, one can presume that realism is less linked to detailed representation than to the freedom the Japanese actor has in the play. Quesada thinks likewise about traditional Japanese dance, which he qualifies as "supreme art" for its exquisite esthetical harmony. Quesada compares the theatre he saw in China with that of Japan, and states that where in China virtue triumphs and vice is punished, in Japan the view of life is more complex, and has more realistic nuances (largely inspired on historical epic plays).

According to Quesada, the attractiveness of Japanese culture resides on the eminently artistic temperament of the Japanese people, which seems to be linked with a deeply rooted hygiene of life and great authenticity. This idiosyncrasy "surpasses our admiration and understanding", everything there is "subordinated to the criterion of art, that aims to embellish life, fill it with joy, satisfy the most elevated emotions and the most complex tastes and remove all ugliness from existence" (Quesada, 1914: 80-81). This lofty artistic temperament is the bait that differentiates simple prostitution in Europe and the west from the pure traditions of the geishas and Yoshiwaras (brothels in the red-light district) of Japan. The artistic and esthetical performance saves musmes and yoshiwaras from the dull sex trade of the youngsters in western brothels. This artistic notion of Japanese prostitution frees it from the sinful character it possesses in the west.

The account of his trip around the world ends with a statistical recount: Quesada traveled 36440 miles, stayed in 50 hotels and took 21 steamboats (Quesada, 1914: 84). From Japan, he continues his travel through Hawaii, Canada and the United States before returning to Buenos Aires. Again he insists, by way of excuse, on the character of "picturesque" of his observations, 
which led him to put aside his probably more interesting sociological and cultural impressions.

\section{CONCLUSION}

The writings of Quesada here analyzed are, on one hand, a clear example of the travels of the Argentinean generations of the 1880 s and 1890 s, and, in the same manner, a sample of the cosmopolitan discourse that grows and triumphs in the years just before the centenary. On the other hand, these texts are different from other testimonies of the time (excepting the writings of Eduardo Wilde, which are undoubtedly more exhaustive and elaborated), as he has scientific pretentions, unlike his peers. Indeed, the originality and ambivalence of Quesada resides in this last aspect. We are not faced with the testimony of a dandy -as in Cané (1994)- or a writer that only seeks the simple entertainment of his readers -like Lucio V. Mansilla. Neither is his work a messy touristic catalogue of vanities at the service of the traveler's image.

A Winter in Russia is the result of an extensive and unusual honeymoon that led Quesada and his wife from the Baltics to Persia. It is part of the writings of his youth, when he was the director of the Buenos Aires Nueva Revista. These first traveling notes are extremely rigorous and show a strong will to learn from the Russian experience, seeking some minimal lessons (though very shy ones) for his own country. On the other hand, the purpose of Journey around the world is different: it is the anecdotal result of a scientific mission aimed to compare the different property rights in the world. However, notwithstanding the judicial objective of the initiative, this extensive conference -pronounced before a female audience- has notable contradictions, and oscillates between a merely touristic register and a temperament opposed to this type of popular travel.

\section{ACKNOWLEDGEMENTS}

English translation by Cristina Labarca.

\section{NOTES}

1. In two volumes. Several chapters of the first part were initially published in Nueva Revista de Buenos Aires. The second part, that should recount memories of the Black Sea, the Caucasus and the Caspian Sea would remain a promise and was never to be edited (Quesada 1888: I, 10). These collaborations, sent to Buenos Aires, never appeared in the magazine, as it was closed in 1885. If the manuscripts were not destroyed during WWII, perhaps they are to be found in the E. Quesada fund of the Iberian-American Institute of Berlin. The Institute was born out of the donation of the library and archives of the Quesada, father and son.

2. Text of the conference at the National Council of Women on May 27th, 1914. Initially published in two parts: Nosotros magazine, year VIII, issue XV, $\mathrm{N}^{\circ} 63$ and 64 of the same year.

3. According to the Jewish Encyclopedia, the first modern pogrom can be traced back to 1821 , when the first anti-Semite attacks occurred in Odessa. The Jewish revolts were recurrent during the 19th century because of extremely repressive conditions, and continued way into the 20th century. In 1905, 2500 Jews were assassinated in Odessa (Weinberg, 1992). See also the Jewish Encyclopedia http://www.jewishencyclopedia.com [accessed 15/November/2012].

4. The essay is a plea in favor of Germany and against England; it is a supplement of the magazine Revista Argentina de Ciencias Politicas, IX; see Quesada (1915a).

5. In this conference held in Berlin between November 15th, 1884 and February 26th, 1885, the European potencies divided the areas of influence in Africa, tracing a new political colonial geography.

6. Founded in the final third of the 19th century by Helena Blavatsky and later furthered in the beginning of the 20th century by Annie Besant, the theosophical theory was aimed at three objectives: "A) form a nucleus of the Universal Fraternity of Humanity, with no distinction of race, belief, sex, chaste or color; B) incentivize the comparative studies of religions, philosophies and sciences; and C) study unexplainable laws of Nature and the latent forces in man". (cf. Revista de la Federación Teosófica del Uruguay, No.1, p.1, October 1924, Montevideo).

\section{REFERENCES}

Aldao, Carlos A. (1914) A través del mundo. 5th enlarged edition. Librería del Colegio [imprenta Ed. Garnier, Chartres], Buenos Aires.

Bujaldón de Esteves, Lila (2006) Historia de la Germanística Argentina. Anuario Argentino de Germanística, Anejo I. Asociación Argentina de Germanistas, Buenos Aires.

Cané, Miguel (1994) En viaje [1884]. Editorial Claridad, Buenos Aires.

Gasquet, Axel (2007) Oriente al Sur, el orientalismo literario argentino de Esteban Echeverría a Roberto Arlt. Eudeba, Buenos Aires.

Gasquet, Axel (2012) “Omar Khayyam's Epicureanism: the Spanish Translations of Rubaiyats (1904-1930)". In Peripheral Transmodernities: South-to-South intercultural dialogues between the Luso-Hispanic World and "the Orient", edited by López-Calvo, Ignacio. Cambridge Scholars Publishing, Newcastle, pp. 157-177.

Gasquet, Axel (2013) "Panthéisme et orientalisme chez Joaquín V. González (Kabir, Tagore et Khayyam)". In Les Orients désorientés, décronstruire l'orientalisme, edited by Dubost, Jean-Pierre and Gasquet, Axel. (in press).

López, Lucio Vicente (1869a) "Ramayana. Poema sánscrito de Valmiki". Revista de Buenos Aires, XX (78): 208-223. http:// archive.org/stream/larevistadebueno20buenuoft\#page/208 [accessed 15/November/2012]

López, Lucio Vicente (1869b) "Ramayana. Poema sánscrito de Valmiki”. Revista de Buenos Aires, XX (79): 418-427. http:// archive.org/stream/larevistadebueno20buenuoft\#page/418 [accessed 15/November/2012]

Noé, Julio (1919) "Prefacio to Carlos Muzio Sáenz-Peña". In Samsara (poemas cortos). Imprenta Mercatali, Buenos Aires.

Obligado, Pastor S. (1873) Viaje a Oriente. De Buenos Aires a Jerusalén. Imprenta Americana of Rouge, Dunon and Fresné, Paris.

Quesada, Ernesto (1888) Un invierno en Rusia. Primera parte, de Berlin a Kursk. Jacobo Peuser, Buenos Aires.

Quesada, Ernesto (1895) La politica chilena en el Plata. A. Moen, Buenos Aires. http://www.archive.org/details/lapolticachilen02quesgoog [accessed 15/November/2012]

Quesada, Ernesto (1899) La política argentina respecto de Chile (1895-1898). A. Moen, Buenos Aires. http://www.archive.org/ details/lapolticaargent00quesgoog [accessed 15/November/ 2012]

Quesada, Ernesto (1902) La política argentino-paraguaya. Librería Bredahl, Buenos Aires. http://www.archive.org/details/historia diplomt00quesgoog [accessed 15/November/2012]

Quesada, Ernesto (1910) La enseñanza de la Historia en las universidades alemanas. Facultad de Ciencias Jurídicas y Sociales, UNLP, La Plata.

Quesada, Ernesto (1914) Una vuelta al mundo. Sociedad Cooperativa Limitada "Nosotros", Buenos Aires. 
Quesada, Ernesto (1915a) El "peligro alemán” en Sud América. Offprint of Revista Argentina de Ciencias Politicas, IX: 75. Talleres Gráficos de Selin Suárez, Buenos Aires.

Quesada, Ernesto (1915b) La legislación inmobiliaria tunecina. Academia de Derecho y Ciencias Sociales, Buenos Aires.

Quesada, Ernesto Quesada (1916) El nuevo panamericanismo y el Congreso Científico de Washington. Ministerio de Agricultura de la Nación, Buenos Aires.

Quesada, Ernesto (1919a) Primera Conferencia Panamericana, Washington, 2/10/1889-19/4/1890. Imprenta Schenone, Buenos Aires.

Quesada, Ernesto (1919b) La evolución del panamericanismo. Ministerio de Agricultura de la Nación, Buenos Aires.

Quesada, Ernesto (1923) El Paraguay y la política brasileroargentina. Talleres Gráficos Araujo, Buenos Aires.

Rivarola, Rodolfo (1917) Filosofía, Politica, Historia. Lecturas en la Facultad de Filosofia y Letras. Librería La Facultad de Juan Roldán, Buenos Aires.

Roig, Arturo Andrés (1972) El espiritualismo argentino entre 1850 y 1900. Editorial José M. Cajica, Puebla.
Soler, Ricaurte (1968) El positivismo argentino. Paidós, Buenos Aires.

Traverso, Enzo (1996a) Pour une critique de la barbarie moderne. Éditions Page Deux, Cahiers libres, Lausanne.

Traverso, Enzo (1996b) Los marxistas y la cuestión judía. Ediciones del Valle, Buenos Aires.

Weinberg, Robert (1992) "The Pogrom of 1905 in Odessa: A Case Study". In Pogroms: Anti-Jewish Violence in Modern Russian History, edited by Klier, John D. and Lambroza, Shlomo. Cambridge University Press, Cambridge-New York, pp. 248289.

Wilde, Eduardo F. (1892) Viajes y observaciones. Imprenta de La Prensa, Buenos Aires. http://archive.org/details/viajesyobser vaci01wild and http://archive.org/details/viajesyobservaci02 wild [accessed 15/November/2012]

Wilde, Eduardo, F. (1899) Por mares i por tierras. Jacobo Peuser, Buenos Aires. http://archive.org/details/pormaresportierr00 wild [accessed 15/November/2012] 